\title{
Transitivity Analysis of Proverbs in Achebe's A Man of the People
}

\author{
Emodi Livina Nkeiruka ${ }^{1}$ \\ ${ }^{1}$ Chukwuemeka Odumegwu Ojukwu, University, Department of English, Igbariam Campus, Nigeria \\ Correspondence: Emodi Livina Nkeiruka, Chukwuemeka Odumegwu Ojukwu, University, Department of \\ English, Igbariam Campus, Nigeria. E-mail: livinaemodi@yahoo.com
}

Received: July 13, $2021 \quad$ Accepted: August 23, $2021 \quad$ Online Published: September 7, 2021
doi:10.5539/ijel.v11n5p77

\begin{abstract}
The language of literary texts is adorned with proverbs, a cultural element which to some extent has become significant in the growth and development of African literature and in the portrayal of meaning assigned by the writer. This paper explores the relationship between linguistic structures and culturally constructed meaning in Chinua Achebe's novel A Man of the people by critically examining the transitivity of proverbs used in the work. This study is anchored on Halliday's Systemic Functional Grammar. The analysis reveals that Achebe uses more material processes, followed by mental processes and then relational and verbal processes. Furthermore, the types of transitivity process, participants, circumstatials contribute towards the construction of themes reflected in the novel. Based on the results, the paper concludes that Achebe uses a variety of transitivity processes as proposed by M.A.K. Halliday with the exception of existential and behaviour. He uses actors, sensers, carriers, identifiers, to convey message of his novel. Achebe mostly uses circumstances of extent, location, and manner to show that the actions take place in a certain place, time, and at a certain frequency. The paper concludes that Achebe's use of varieties of processes, participants and circumstances has made his novel interesting and readable.
\end{abstract}

Keywords: transitivity, proverbs, a man of the people, systemic functional grammar, process

\section{Introduction}

Examining the language of a literary text can be a means to understanding and appreciating the writer's artistic achievement (Leech \& Short, 2007). This is true as language conveys the message of the writer. Proverbs are one of the genres and culture- related communication strategies that African literary artists often embrace in their writing. This study explores the relationship between linguistic structures and culturally constructed meaning in Achebe's A Man of the People by critically examining the transitivity as encapsulated in the proverbs used.

A proverb is a traditional saying that expresses a perceived truth based on common sense or experience. Several scholars have attempted to define proverbs in several ways depending on their purposes and points of view. Nwoga (cited in Asika, 2013) defines proverb as a 'terse statement which figuratively gives expression to traditional wisdom relevant to a given situation'. Achebe (2008) views it as 'the palm oil with which words are eaten'. Umeasiegbu (2007) sees proverb as any expression recognized by a people as embodying the wisdom and philosophy of their ancestors. He admits that the definition has its pitfall but the strength lies in the words recognized by people as embodying the wisdom and philosophy of their ancestors. Onuekwusi, (cited in Asika, 2017) believes that proverbs are pleasant expressions which adorn the rhetoric of a people. Proverbs constitute a part of the oral tradition of a people, which is unconsciously acquired. Onuekwusi defines a proverb is a philosophical, allusive and metaphorical citation that gives credence to traditional truth and wisdom. It is allusive and metaphorical because it refers to some truth outside itself. It is philosophical because it is a product of a long period of reasoning and observation which expresses some timeless truth. Okpewho (1992) defines proverbs as "a piece of folk wisdom expressed with terseness and charm." Finnegan (1970) defines proverb as "a saying in more or less fixed form marked by shortness, sense and salt and distinguished by the popular acceptance of the truth tersely expressed in it". Therefore, a proverb is a compressed pithy statement which embodies a conventional truth universally accepted by different generations in a given culture. It can also be described as a short, pithy statement of a general truth, one that condenses common experience into a memorable form. The study will seek to discover how process types, participants, and circumstance are utilized in proverbs by Achebe in portraying meanings in his novel. In other words, it is anchored on Systemic Functional Grammar Transitivity. The objectives of the study include (i) to identify proverbs in Achebe's A Man of the People, (ii) to categorize proverbs into clauses, and (iii) to conduct transitivity analyses on the categorized clauses to show how 
Hallidayan transitivity can help in portraying the meaning of Achebe's book.

\section{A Brief Account of Achebe's A Man of the People}

A Man of the People is a first-person account of Odili, a school teacher in a fictional country closely resembling post-colonial Nigeria. Odili receives an invitation from his former teacher, Chief Nanga, who is now the powerful but corrupt Minister of Culture. As Minister, Nanga's job is to protect the traditions of his country especially when he is known as 'A Man of the People'. Instead, his position is used to increase his personal wealth and power. While Odili is with him, Nanga allures Odili's girlfriend and she cheats Odili with the minister. Seeking revenge, Odili begins to pursue the minister's fiancée, Edna. Odili agrees to lead an opposition party in the face of both bribes and violent threats and he is to context Chief Nanga's position. Then there is a military coup.

\section{Theoretical Background}

\subsection{Systemic Functional Grammar}

Systemic Functional Grammar (SFG) is an effective framework for describing and modelling language as a resource for making meaning and discourse choices. This framework treats language beyond its formal structures and takes the context of culture and the context of situation in language use into consideration (Martin \& Rose, 2003). SFG is associated with the linguists of the London School, specifically Halliday, in the 1960s whose immediate goal in stylistic analysis is 'to show why and how the text means what it does (Halliday \& Matthiessen, 2004) according to them, meaning in texts is determined by context of culture, context of situation, and metafunctions.

Context of culture according to Halliday and Matthiessen (2004) means the meanings and assumptions we share as a community of people. It also incorporates culturally evolved expectations of ways of behaving and how things are done. What this means is that language is conditioned by the context of culture. It is produced within a culture. Culture is important to understand the history behind a speech event as it relates to the values and norms of a speech community (Opara, 2017). To her, culture is 'a set of beliefs and meanings a group gives to their world'. Context of situation is the particular context in which the text is produced and it conditions the lexico-grammar of a text and has been defined by Lipson as 'the sum of the motivating features of the text's construction' (cited in Opara, 2017). It refers to the participants in the milieu (situation) with their words and actions (verbal and non-verbal) and to the relevant objects in the situation which indicate verbal and non-verbal events, and the effect of the verbal action. Context of situation according to Melrose (1995) is the "behaviour potential' of a participant and she characterised it in terms of field, mode, and tenor (cited in Opara, 2017). She explains that field of discourse refers to the social situation and subject matter which stands for the area of operation of linguistic activity that yields the various register we have in different disciplines Mode of discourse refers mainly to the channel of communication, as whether it is spoken or written. Stubbs (1986) holds that mode is the medium of transmission, usually speech or writing and further argues that tenor refers to the formality and social relations between the participants; Stubbs (1986) sees discourse in terms of the linguistic repertoire of the language user. He contends that, in a typical first language situation, individuals have native command of one dialect but have command of diatypes - that is, they change their language according to what they are talking about, where they are, and so on. The most general dimension which determines the diatypes, Stubbs (1986) further states, is the formality of the social context: intimate, casual, or more formal. Diatypes manifest extensively in discourse. But Opara (2017) states that tenor refers to the relationship between the participants which could be that between speaker (and writer) and hearer (or reader) and adds that novelists indicate this relationship among their interlocutors (or characters).

The three contextual categories of field, tenor, and mode are realised by the three metafunctions-ideational, interpersonal, and textual. While field is experiential, tenor is interpersonal, mode is textual. Among the three metafunctions, field determines the transitivity pattern (Halliday \& Mathiessen, 2004). Metafunctions are (a) textual, providing links between language and the features of the situation in which it is used; (b) ideational serves the speaker's experience of the real world, including the inner world of his own consciousness and (c) interpersonal, establishes and maintains social relations. Fowler (1996) adds that the ideational metafunction interprets, organizes, and classifies the subjects of discourse by representing how the world is perceived. Further, the ideational function consists of processes, participants, and circumstances and these are what we shall be discussing in Achebe's proverbs in terms of transitivity. Transitivity is an important grammatical issue and has been an important topic in linguistic theories.

Transitivity in Halliday's systematic functional theory is referred to as 'a system for describing the whole clause, rather than just the verb and the object' (Huijing, 2015) as in traditional grammar. To Halliday and Matthiessen (2004), transitivity represents our experience "which consists of 'going-on, happening, doing, sensing, meaning, 
and being and becoming'. It is a system of the clause, affecting not only the verb serving as process but participants and circumstances (Halliday \& Matthiessen, 2004). As well as being a mode of action, of giving and demanding goods and services and information, the clause is a mode of reflection, of imposing order on the endless variation and flow of events (Huijing, 2015) people construe the complex world on the basis of transitivity system which helps to sort out experiences and divide them into a manageable set of process types. The semantic processes expressed by clauses have three components:

(1) Process which will be expressed by the verb phrase in a clause e.g., material, mental, relational, behavioural, verbal and existential.

(2) The participants involved in the process. These roles are typically relayed by noun phrases in the clause.

(3) The circumstances associated with the process, normally expressed by adverbial and prepositional phrases.

\subsection{Processes}

The presence and type of processes depend mainly on the participants involved, their number and type, as well as on the process itself. Halliday distinguishes six different types of processes.

\subsubsection{Material Processes}

This type of process includes clauses of doing and happening. It construes a quantum of change in the flow of events as taking place through some input of energy (Halliday \& Matthiessen, 2004). In a material process, there is always one participant - the actor. The participant brings about the unfolding of the process through time, leading to an outcome that is different from the initial phase of the unfolding. When this outcome is confined to the actor itself such a material clause represents a happening and is called intransitive verb by traditional grammarians. The action of the process may extend to another participant, the goal. Such material process represents 'a doing' and is called a transitive verb. The two main participants associated with this process are: the Actor (the doer of the process) and the Goal (the entity affected by the process). Example: The lion caught the tourist. Here, 'the lion' is an actor, 'caught' is material process, while the tourist is the goal.

\subsubsection{Mental Processes}

Mental clauses are concerned with our experience of the world of our consciousness (Halliday \& Matthiessen, 2004). In a mental clause, the subject is the speaker which is a nominal group denoting a conscious being such as 'I' but the complement is realised by a nominal group that can denote entities of any kind-animals, objects, abstractions, such as greed. Mental processes are grouped into four subtypes which are perception (see, hear, feel), cognition (know, understand, believe), affection (like, love), and desire (hope, want, wish). Within this process, there is always a conscious participant known as the sensor: the one who perceives, knows, likes, etc. In addition to the sensor, there is another participant involved in the mental processes which is the phenomenon which is felt, perceived, known, thought, or wanted.

\subsubsection{Relational Processes}

Relational processes are typically realized by the verb 'be' or some verbs of the same class (known as copular verbs); for examples, 'seem', 'become, 'appear', or sometimes by verbs as 'have' 'seem', 'become', appear', etc, or sometime by verbs such as 'have', 'own', 'possess'. Halliday and Matthiessen state that relational processes are divided into two modes: identifying relational process and attributive relational process. In the identifying mode, something has an identity assigned to it. It means that one entity is being used to identify another: ' $\mathrm{X}$ is identified by A' or 'A serves to define the identity of X' (Halliday \& Matthiessen, 2004). The $X$-element is labelled as identified, and the ' $\mathrm{A}$ ' element is labelled as identifier, which serves an identity. This mode is realized by the verbs: 'to be': (is, are, were am was ...), and 'become' etc. Attributive relational processes are the processes which assign a quality. ' $A$ ' is an attribute of ' $X$ '. In other words, in this mode, an entity has some quality ascribed or attributed to it (Halliday \& Matthiessen, 2004). This type is realized by the verbs: 'sound', 'look', 'play', 'cost', 'have', 'get', 'seem', etc. The participants for attributive clauses are carrier and attribute while those for identifying clause are identified and identifier.

\subsubsection{Behavioral Processes}

Behavioural processes are characterized by the outer expression of inner working and reflected physiological and psychological behaviours. This type of process usually has one participant who is typically a conscious one, called the Behaver. Examples include breathing, coughing, smiling, dreaming, chatting, watching.

\subsubsection{Verbal Processes}

The verbal processes represent the act of saying. Usually, three participants are involved in Verbal processes: the 
Sayer is responsible for the verbal process; the Receiver is the person at whom the verbal process is directed; and the Verbiage is the nominalised statement of the verbal process. Examples of verbal processes include 'say' and 'tell'.

\subsubsection{Existential Processes}

Existential processes which show state of being, existing, and happening. They are concerned with existence by which phenomena of all kinds are simply recognized to be - to exist or to happen. Existential processes typically employ the verb 'be' or its synonyms such as 'exist', 'arise', 'occur'. The only participant in this process is 'existent' which follows the 'there is/are' sequences (a non-participant) as a subject of the clause.

\subsubsection{Circumstantial}

Circumstances are meaning which contextualises the events construed in the clause according to such dimensions as time, place and manner (Halliday \& Matthiessen, 2004). They are the adverbials and prepositional phrases. Bloor and Bloor (2004) state concerning circumstantial:

Circumstantial is the name given to those elements which carry a semantic load but are neither process nor participant. It is more concerned with matters as the setting, temporal and physical, the manner in which the process is implemented, and the people or other entities accompanying the process rather than directly engaged in it. Circumstances conflate with adjunct and the grammatical realization is adverb or prepositional phrase 134 .

The elements we are treating as Circumstantial are those in which the participant typically—and in many cases obligatorily - is indirect, being linked into the process via some preposition or other (Halliday \& Matthiessen, 2004). 'Indirectly' in this sense, means that although the prepositional phrase has a nominal group, it is not the exact participant functioning in the clause. Halliday and Matthiessen (2004) recorded nine types of circumstantial to include: extent, location, manner, cause, contingency, accompaniment, role, matter, and angle.

Extent construes the extent of the unfolding of the process in space-time: the distance in space over which the process unfolds or the duration in time during which the process unfolds (Halliday \& Matthiessen, 2004, p. 264). The interrogative forms for extent are 'how far?', 'how long?', 'how many?', 'how many times?' The typical structure is a nominal group with quantifier, either definite e.g., 'five days' or indefinite e.g., 'many miles', 'a long way'. They occur either with or without preposition. The most usual preposition is 'for'. On the other hand, location construes the location of the unfolding of the process in space-time: the place where it unfolds or the time where it unfolds. Interrogatives of location includes 'when' and 'where'. 'Place' and 'time' here do not only involve static location in space and time but also the source, path, and destination of movement. Time also includes the temporal analogues of source, path, and destination. Examples of extent include 'everyday', 'all day long', 'near the lamp' etc. Examples of location include: 'outside the station', 'into the street', 'right again at the park', 'at the George street', 'to saint Andrew street'.

The circumstantial element of manner construes the way in which the process is actualized. Manner comprises four categories: Means, Quality, Comparison, and Degree. Means refers to a means whereby a process takes place; it is typically expressed by a prepositional phrase with the preposition 'by' or 'with'. The interrogative forms are 'how' and 'what with' Examples: 'by experiment', 'by means of a written word', 'through heresy', 'on your hind legs' etc. Quality is expressed by an adverbial group, with '-ly' adverb as head. The interrogative is 'how' or 'how plus appropriate adverb'. Examples include 'well', 'calmly', 'in a certain way'. Comparison is typically expressed with a prepositional phrase with 'like' or 'unlike' or adverbial group with similarity or difference examples like 'a pillar in the course of their history', 'like the devil', 'like all Mayan boys', 'like a shield in front of his uncle', 'unlike Proust'. Interrogative is 'what... like'. Degree is expressed by an adverbial group with a general indication of degree such as 'much', 'a good deal', 'a lot' or with a more restricted adverb of degree such as 'deeply', 'profoundly', 'completely', 'heavily'.

The circumstantial element of cause construes the reason why the process is actualized. It includes both reason why, purpose, and the circumstances of behalf. Reason represents the reason for which a process takes place - which cause it; they have the sense of because. It is expressed with a prepositional phrase with though, from, or or a complex preposition such as because of, as a result of, thanks to, for want of. Purpose represents the intention behind the cause of an action. They are expressed by a prepositional phrase 'with for', 'as in the hope of', 'for the purpose of', 'for the sake of'. 'Behalf' represents the entity, a person, on whose behalf or for whose sake the action is undertaken - who it is for. They are expressed by prepositional phrase with for, "for the sake of', 'in favour of', 'against' (negative), 'on behalf of'.

Circumstances of contingency specify an element on which the actualization of process depends. Contingency 
involves condition, concession, and default. Condition construes circumstances that have to obtain in order for the process to be actualized; they have the sense of 'if'. They are expressed by prepositional phrases like 'in case of', 'in the event of', 'on condition of'. Concession construes frustrated cause, with the sense of 'although'. They are expressed by prepositional phrases with the prepositions 'despite', 'notwithstanding', 'in spite of', 'regardless of'. Default have the sense of negative condition - 'if not', 'unless'. They are expressed by prepositional phrases with the complex prepositions 'in the absence of', 'in default of.

Accompaniment is a form of joint participation in the process and represent the meanings and, or, not as circumstantial; it corresponds to the interrogatives 'and who'/ 'what else?' but not 'who'/'what?' It involves both comitative (positive and negative) and additive (positive and negative). The comitative represents the process as a single instance of a process, although one in which two entities are involved. It ranges from some cases where the two entities could be conjoined as a single element e.g., Fred and tom set out together, to others, where they could not like Jane and her umbrella set out together. Examples: with my father, with about 50 other people. Additive represents the process as two instances; where both entities clearly share the same participant function, but one of them is represented circumstances for the purpose of contrast. Example 'Fred came as well as Tom', 'not only but', 'in collaboration with'.

Role construes the meanings 'be' and 'become' circumstantially. It corresponds to the attribute or value of an intensive relational clause. It includes: guise and product. Guise corresponds to the interrogative 'what as' and construe the meaning of 'be' (attribute or identity) in the form of circumstances. Examples include 'she was installed as chancellor', 'I come here as a friend' (she is the chancellor, I am friendly). Prepositions are: 'as', 'by way of', 'in the role/shape/guise/form of'. Product, on the other hand, corresponds to the interrogative 'what into' with the meaning 'becoming' e.g., 'Aren't you growing into a big girl', (becoming a big girl), 'he moulded the army into a disciplined fighting force'.

Matter is related to verbal processes; it is the circumstantial equivalent of the verbiage, that which is described, referred to, narrated. The interrogative is 'what about?' Matter is expressed by preposition such as 'about', 'concerning', 'with reference to', and 'sometimes of'. Example: Tell me about the Paris review.

Angle is related to either the sayer of a verbal clause, with the sense of as 'say' or to the senser of a mental clause with the sense of as ... 'thinks'. It is expressed by such phrases as: 'according to him', 'in the word of', 'showing source of' 'and such expressions as' 'in the view/opinion of, 'from the standpoint of', 'for example showing viewpoint'.

\section{Identification of Proverbs in A Man of the People}

1) Micah's handsomeness, which he likened to the perfect, sculpted beauty of a carved eagle, and his popularity which would be the envy of the proverbial traveller-to-distant-places who must not cultivate enmity on his route (p. 1).

2) If you thought that a sensible man would spit out the juicy morsel that good fortune placed in his mouth (p. 2).

3) They have bitten the finger with which their mother fed them (p. 6).

4) It is better the water is spilled than pot broken (p. 30).

5) When one slave sees another cast into a shallow grave, he should know that when the time comes he will go the same way (p. 38).

6) Bad children that crunched their mother's skull (p. 3).

7) A man who has just come in from the rain and dried his body and put on dry clothes is more reluctant to go out again than another who has been indoors all the time (p. 40).

8) In our country, a long American car driven by a white uniformed chauffeur and flying a ministerial flag could pass through the eye of a needle (p. 60).

9) Uneasy lays the head that wears the crown (p. 65).

10) It was like the man in the proverb who was carving the carcass of an elephant on his head and searching with his toes for a grasshopper (p. 77).

11) When an old woman hears the dance she knows how to dance, she knows her old age deserts her (p. 72).

12) As the saying goes, it is only when you are close to a man that you can begin to smell his breath (p. 90).

13) I have said that what the white man's money will bring about had not shown itself yet (p. 91).

14) What money will do in this land wears a hat (p. 92). 
15) Our people have a saying that if you respect today's king, others will respect you when your turn comes.

16) Our people say: if you fail to take away a strong man's sword when he is on the ground, will you do it when he gets up...?

17) Josiah has taken away enough for the owner to notice (p. 93).

18) Some people's belly is like the earth, it is never so full that it will like to take another corpse (p. 93).

19) My brother when those standing have not got their share you are talking about those kneeling (p. 94).

20) If I am not to grow bigger let me at least remain as small as I am (p. 96).

21) I see that you have grown too big for your coat (p. 111).

22) My in-law is like a bull he said and your challenge of a tick to a bull. The tick fills its belly with blood from the back of the bull and the bull doesn't even know it is there. He carried it wherever he goes - to eat, drink or pass ordure. Then one day the cattle egret comes, perches on the bull's back and picks out the tick... (p. 115).

23) I felt a tingling glow of satisfaction spread over me as palm oil does on hot yam (p. 117).

24) When a mad man walks naked, it is his kinsmen who feel shame not himself (p. 128).

25) If alligator comes out of the water, one morning and tells you that crocodile is sick, can you doubt his story (p. 132)?

26) I believe that the hawk should perch and the eagle perch, whichever says to the other don't, may its own wing break (p. 134).

27) If I fall for you this time and you for me next time, then I know it is play not fight (p. 136).

28) He should tell them that we are waiting here like a babe cutting its first tooth: anyone who wants to look at our new tooth should know that his bag should be heavy (p. 137).

29) If the very herb we go to seek in the forest now grows at our very back yard are we not saved the journey (p. 137)?

30) My people this is the boy who is thrusting his finger into my eyes (p. 151).

31) Koko has taken enough for the owner to see (p. 161).

\section{Categorization of Clauses}

Table 1. Categorization of clauses

\begin{tabular}{|c|c|c|c|c|}
\hline $\mathrm{S} / \mathrm{N}$ & PROCESS TYPE & FREQ \& \% & EXAMPLES & CIRCUMSTANTIAL \\
\hline 1 & Material process & $51 / 49.5 \%$ & $\begin{array}{l}\text { 1. that a sensible man would spit out the juicy morsel } \\
\text { 2. that he will go the same way } \\
\text { 3. If I fall for you this time } \\
\text { 4. you fall for me next time } \\
\text { 5. than pot broken. } \\
\text { 6. who has just come in from the rain } \\
\text { 7. who has dried his body } \\
\text { 8. who has put on dry clothes } \\
\text { 9. who was carving the carcass of an elephant on his head } \\
\text { 10. who was searching with his toes for a grasshopper. } \\
\text { 11. Those kneeling } \\
\text { 12. will you do it } \\
\text { 13. when he gets up...? } \\
\text { 14. that the hawk should perch } \\
\text { 15. the eagle perch } \\
\text { 16. may its own wing break. } \\
\text { 17. They have bitten the finger } \\
\text { 18. with which their mother fed them } \\
\text { 19. In our country, a long American car driven by a white } \\
\text { uniformed chauffeur } \\
\text { 20. In our country, a long American car flying a ministerial flag } \\
\text { 21. It could pass through the eye of a needle } \\
\text { 22. When a mad man walks naked }\end{array}$ & $\begin{array}{l}\text { 1. the same way } \\
\text { 2.This time } \\
\text { 3. for you (cause) } \\
\text { 4. Next time } \\
\text { 5.from of the rain } \\
\text { 6. With his toe } \\
\text { 7.for a grasshopper } \\
\text { 8.On his head } \\
\text { 9. When he goes up } \\
\text { 10.By a white uniformed } \\
\text { chauffeur } \\
\text { 11. In our country } \\
\text { 12.Through the eye of a } \\
\text { needle } \\
\text { 13. naked } \\
\text { 14.Into his eyes } \\
\text { 15.On the bull back } \\
\text { 16.Out of water } \\
\text { 17.One morning } \\
\text { 18.In the forest, } \\
\text { 19. now } \\
\text { 20.In this land } \\
\text { 21. enough }\end{array}$ \\
\hline
\end{tabular}


23. who is thrusting his finger into my eyes.

24. He carried it

25. wherever he goes - to eat, drink or pass ordure

26. Then one day the cattle egret comes,

27. The egret perches on the bull's back

28. The egret picks out the tick

29. As palm oil does on hot yam.

30. a babe cutting its first tooth

31. when your turn comes

32. If alligator comes out of the water, one morning

33. If the very herb we go to seek in the forest now

34. Bad children that crunched their mother's skull

35. What money will do in this land

36. It wears a hat

37. Josiah has taken away enough for the owner to notice

38. Koko has taken enough for the owner to see

39. that what the white man's money will bring about

40. When one slave sees another cast into a shallow grave

41. when the time comes

42. If I am not to grow bigger

43. You don't

44. that you have grown too big for your coat

45. that wears the crown

46. when those standing

47. they have not got their share

48. if you fail to take away a strong man's sword

49. The tick fills its belly with blood from the back of the bull

50. the water is spilled

51. A man is more reluctant to go out again than another

52. that good fortune placed in his mouth

53. that we are waiting here

\begin{tabular}{|c|c|c|c|c|}
\hline 2 & Mental process & $27 /, 26.2 \%$ & $\begin{array}{l}\text { 1. If you thought } \\
\text { 2. he should know that } \\
\text { 3.let me at least remain as small as } \\
\text { 4. I believe } \\
\text { 5. When an old woman hears the dance } \\
\text { 6. she knows how to dance, } \\
\text { 7. she knows her old age } \\
\text { 8. it deserts her. } \\
\text { 9. when you are close to a man } \\
\text { 10. that you can begin to smell his breath } \\
\text { 11. it had not shown itself yet } \\
\text { 12. who feel shame not himself } \\
\text { 13. the bull doesn't even know. } \\
\text { 14. I felt a tingling glow of satisfaction spread over me } \\
\text { 15.who wants to look at our new tooth } \\
\text { 16. anyone should know } \\
\text { 17. Can you doubt his story? } \\
\text { 18. if it grows at our very back yard } \\
\text { 19. Are we not saved the journey? } \\
\text { 20. Uneasy lays the head } \\
\text { 21. I see } \\
\text { 22.that it will like to take another corpse } \\
\text { 23. then I know } \\
\text { 24. that if you respect today's king } \\
\text { 25. Others will respect you }\end{array}$ & $\begin{array}{l}\text { 31. In his mouth } \\
\text { 32. When the time comes } \\
\text { 33. When those standing } \\
\text { 34. As small as } \\
\text { 35. When an old woman } \\
\text { hears the dance } \\
\text { 36. When you are close } \\
\text { to a man } \\
\text { 37. yet } \\
\text { 38. At our new tooth }\end{array}$ \\
\hline 3 & Relational process & $16 / 15.5 \%$ & $\begin{array}{l}\text { 1. Some people's belly is like the earth } \\
\text { 2. it is never so full } \\
\text { 3. it is play not fight } \\
\text { 4. It is better } \\
\text { 5.who has been indoors all the time }\end{array}$ & $\begin{array}{l}\text { 39. Like the earth } \\
\text { 40. Never } \\
\text { 41. So full } \\
\text { 42. all the time } \\
\text { 43. Like the man }\end{array}$ \\
\hline
\end{tabular}

22. About

23. Into a shallow grave.

24. Bigger

25. Too big for your coat

26. with blood

27.From the back of the

bull

28. out

29. again

30. here 


\begin{tabular}{|c|c|c|c|c|}
\hline & & & 6. It was like the man in the proverb & 44. in the proverb \\
\hline & & & 7. I am something & 45. When he is \\
\hline & & & 8. when he is on the ground & on the ground \\
\hline & & & 9. it is only & 46. Only \\
\hline & & & 10. it is his kinsmen & 47. on the ground \\
\hline & & & 11. My people this is the boy & 46.Like a bull \\
\hline & & & 12. My in-law is like a bull & 47. Like of a tick to a \\
\hline & & & 13. your challenge is like of a tick to a bull & bull \\
\hline & & & 14.it is there & 48. there \\
\hline & & & 15.that his bag should be heavy & 49. heavy \\
\hline & & & 16. that crocodile is sick & \\
\hline 4 & Verbal process & $9 /, 8.7 \%$ & 1. My brother you are talking about & 50. about \\
\hline & & & 2. Our people say & \\
\hline & & & 3. whichever says to the other & \\
\hline & & & 4. As the saying goes & \\
\hline & & & 5. I have said & \\
\hline & & & 6. he said & \\
\hline & & & 7. Our people have a saying & \\
\hline & & & 8. He should tell them & \\
\hline & & & 9. he tells you & \\
\hline 05 & Existential process & 0 , & & \\
\hline 6 & $\begin{array}{l}\text { Behavioural } \\
\text { process }\end{array}$ & 0 & & \\
\hline & & $103 / 100 \%$ & & $50 / 100 \%$ \\
\hline
\end{tabular}

\section{Analysis}

The research subject for this study is proverbs in A Man of the People. Thirty-one proverbs are identified from the novel. Out of these, only few are purposively selected for the analysis. Purposive sampling was found appropriate for this kind of research, because apart from saving a lot of time and resources, it made it possible to undertake a safe and systematic selection of samples from a vast array of data. Each selected proverb is broken down into clauses. They are also categorised as transitive and intransitive clauses. These categorisations enable us to know which clause can be analysed and which can't be analysed based on the process type, participant and circumstantial options. Next, the selected options are categorized. These clauses should be put in table containing the participants, processes, and circumstances. Each clause is analysed with reference to the proverb in which it is extracted from. The analysis is based on the contributions of the processes, participants and circumstances to the meaning of the text.

\subsection{Material Process}

The following are samples of material clauses to be used for analysis.

1) that a sensible man would spit out the juicy morsel

2) that he will go the same way

3) who has just come in from the rain

4) who has dried his body

5) who has put on dry clothes

6) who was carving the carcass of an elephant on his head

7) who was searching with his toes for a grasshopper.

8) Those kneeling

9) that the hawk should perch

10) the eagle perch

11) may its own wing break.

12) They have bitten the finger

13) with which their mother fed them

14) It could pass through the eye of a needle 
15) When a mad man walks naked

16) who is thrusting his finger into my eyes.

17) The egret perches on the bull's back

18) The egret picks out the tick

19) As palm oil does on hot yam.

20) a babe cutting its first tooth

21) It wears a hat.

Table 2. Examples of material process transitivity

\begin{tabular}{|c|c|c|c|c|}
\hline & Actor & Material process & Goal & circumstantial \\
\hline 1 & A sensible man & would spit out & juicy morsel & \\
\hline 2 & he & will go & & \\
\hline 3 & you & has just come & & in, from the rain \\
\hline 4 & who & has dried & his body & \\
\hline 5 & who & has put on & dried clothes & \\
\hline 6 & who & was carving & the carcass from the elephant & \\
\hline 7 & those & kneeling & & \\
\hline 8 & The hawk & should perch & & \\
\hline 9 & The eagle & perch & & \\
\hline 10 & Its own wind & may break & & \\
\hline 11 & They & have bitten & the finger & \\
\hline 12 & Their mother & fed & them & \\
\hline 13 & it & could pass & & through the eye of a needle \\
\hline 14 & who & was searching & & with his toe for a grasshopper \\
\hline 15 & A mad man & walks & & naked \\
\hline 16 & who & is thrusting & his finger & into my eyes \\
\hline 17 & The egret & perches & & on the bull's back \\
\hline 18 & The egret & picks out & the tick & \\
\hline 19 & Palm oil & does & hot yam & \\
\hline 20 & A babe & cutting & its first tooth & \\
\hline 21 & It & wears & a crown & \\
\hline
\end{tabular}

Table 2 shows examples of material process transitivity. They are indicated by the processes 'would spit', 'will go', 'has just come', 'has dried', 'has put on', 'was carving', 'kneeling', 'was searching', 'should perch', 'perch', 'may break', 'have bitten', 'fed', 'could pass', 'works', 'is thrusting', 'perches', 'picks', 'does', 'cutting', 'wears' which are action and doing verbs. The actors are 'a sensible man', 'he', 'you', 'who', 'those', 'the hawk', 'the egret', 'its own wing', 'they', 'their mother', 'it', 'a mad man', 'the egret', 'palm oil', 'a babe' are the performers of the above actions. Some of the clauses are transitive while some are intransitive. Examples of transitive clauses from the list include

1) that a sensible man would spit out the juicy morsel

2) who has dried his body

3) who was carving the carcass of an elephant on his head

4) They have bitten the finger

5) with which their mother fed them

6) who is thrusting his finger into my eyes.

7) a babe cutting its first tooth

8) It wears a hat

These verbs: 'would spit', 'has dried', 'carving', 'have bitten', 'fed', 'is thrusting', 'cutting', are all transitive verbs because they have the objects: 'juicy morsel', 'his body', 'the carcass of an elephant', 'the finger', 'them', 'his finger', 'its first tooth', 'a hat'. It is necessary here to connect the essential linguistic features to the understanding of the message conveyed by Chinua Achebe in making use of these items in his work. In fact, the predominance of material processes over other processes implies that Achebe's world view in his novels highlights 
more actions than any other things. Indeed, nearly all the actions are concrete and tangible in the processes be they transitive or intransitive. A Man of the People was written after independence when the politics of the newly independent state is ruled by a few corrupt individuals. This suggests that Achebe is writing about real and concrete matter of his time and not about abstract issues. Chinua Achebe makes use of the process 'would spit' in such proverb like 'If you thought that a sensible man would spit out the juicy morsel that good fortune placed in his mouth' to shows how corrupt the masses have become at the time. The masses see Nanga's behaviour as normal. To them, embezzlement of public money is a game of politicians and therefore, Nanga is doing the right thing. 'The juicy morsel' that is, the wealth of the nation which he must manage the way he likes because 'good fortune' has given him the opportunity.

Clauses no 2-5 are from the proverb-'A man who has just come in from the rain and dried his body and put on dry clothes is more reluctant to go out again than another who has been indoors all the time'. The process 'has dried' and its participant 'his body' give the impression of the irresistibility of political power. The narrator utters the proverb after witnessing Mr. Nanga's opulent official residence, which immediately prompts him to theorize on man's basic nature. Consequently, he postulates that it is unrealistic to expect a man who enjoys such opulence to voluntarily give up his political appointment, human nature being too weak to resist such attraction. It refers to the hazardous nature of political power in terms of man's inability to resist it, even when he has glaringly overstayed his welcome or to shun the corruption that trails it. It, therefore, follows that the only way to resist political power for its corrupting influence is not to taste it in the first place.

The process 'carving' and the participant 'the carcass of an elephant' give the impression of greedy nature of man in the proverb 'it was like the man in the proverb who was carving the carcass of an elephant on his head and searching with his toes for a grasshopper'. The process 'carving' and the participant 'the carcass of an elephant' metaphorically refer to an insignificant end or aim. The narrator, Odili, employs it in a conventional proverb by which he wonders why he has time to notice inconsequential incidents around him even as he shoulders an overwhelming emotional burden. He is emotionally burdened' because Nanga the famous politician snatched his girl friend from him. As a result of this betrayal, he zooms out of the minister's residence, carrying his bags and luggage. As he walks away in annoyance with no destination in mind, bent on taking an action yet to be decided, he is unable to hold himself from observing such insignificant scenes as shit carriers in active service, sleeping homeless beggars and a scrambling lunatic. Coming back to his senses, later, he considers strange, the fact that he has time to spare on such scenes instead of working out his action plan against his assailant. Hence, thinking aloud, he equates himself with the proverbial greedy fellow who carries the carcass of an elephant on his head, but still searches for a grasshopper with his toes. Unknown to him, he chastises not himself but his country's political leaders. He denigrates not himself, because the insignificant scenes he has taken time to observe speak volumes about the ineffective leadership being offered by the ruling 'POP'.

The process 'have bitten' and the participant 'the finger' in the proverb 'they have bitten the finger with which their mother fed them' shows that Nanga is not ready to entertain any form of criticism by the masses. Criticising him is equal to one beaten his mother. 'Their mother fed them' shows that since Nanga has helped the narrator before, the narrator. Odili, has no right to say anything bad about Nanga.

The process 'wear' appears in a popular utterance: uneasy lies the head that wears the crown. It is made by Elsie, Odili's supposed girlfriend in an ironic support of Mr. Nanga's claim that the office of a minister is a tedious one. The ironic nature of this utterance serves to lampoon the pretension that ideologically characterizes the life of politicians. The full import of this assertion is underlined by Mr. Nanga's subsequent do or die rivalry with Odili for a parliamentarian seat.

As discussed earlier, transitive clauses show that actor's roles are played by human subjects acting on things external to them. They create atmospheres of physical activities and as well suggest that people are the key actors that operate changes in the world created by the novel under study. Since a transitive verb is an action verb, it shows that its relevant noun is doing something, acting on something else, which is the object. By making use of transitive verbs in proverbs, the actions portrayed by the proverbs are made clear and the ideas expressed are complete by linking the meaning to its object. For instance,

i) It has bitten the fingers

ii) It wears a hat

In no i and ii clauses, the actions of 'bitten' and 'wear' are received by the goals 'the fingers' and the 'hat'. Whatever ideas that transpire between the actors and the goals are clear and complete.

But the intransitive verb proverbs do not have objects therefore the actions performed by the actors do not extend 
to anything but stops with the actor. This means that those actors in the novels act not only on their world but also on themselves. We can understand through this that Achebe highlights the diverse transformations that took place in Africa as a whole and on individual lives. Achebe has used these actors and processes to show disillusionment that comes with corruption in the newly independence Nigeria. For instance:

1) If you thought that a sensible man would spit out the juicy morsel that good fortune placed in his mouth 2

2) A man who has just come in from the rain and dried his body and put on dry clothes is more reluctant to go out again than another who has been indoors all the time. 40

In the above proverbs, the actors (a sensible man, another slave, the time, and he and their corresponding processes 'spit', 'come', 'go', 'dried', 'put', explain the issue of political corruption. The first proverb was altered by Odili, the protagonist and the narrator of the story, in his intense bitterness seeing the commoners waiting for chief Nanga who has enriched himself with his position. And the above is the possible answer for him if he should tell them the truth. The second is also said by Odili in his analysis of the political system in the country. For him, it is because he, Odili, has not got an experience in politics that he would want to be made the commissioner. If he has, he wouldn't like to be made one.

The choice between active and passive voice is significant for SFPCA. SFPCA means subject, finite (auxiliary verb), predicate (main verb), compliment, and adjunct. It is important in transitivity analysis since the item which is complement in the active is subject in the corresponding passive but the items retain the same functions of Actor or goal regardless of voice (Bloor \& Bloor, 2004). Achebe seems to have used more of active clauses in his novel because all the clauses chosen for this analysis are all active clauses.

Active voice means that a sentence has a subject that acts upon its verb and the action becomes more important than the performer of the action. While writing in active voice, he uses fewer words, making his writings more concise and efficient. Achebe in using more active voice in his novels, creates faster-moving narratives that are engaging in reading. The use of active voice makes the novel clear and easy to understand.

\subsection{Mental Process}

The mental process formed the second largest group in the novel. The number of mental processes is 27 and the percentage to the total clause is $26.2 \%$. Unlike the material clauses representing the doings of the participants, mental clauses are concerned with the representation of the participant's thoughts, feelings, and perceptions. Here, it is important to state that the four categories of their class as elaborated in Halliday's framework are found. It is worth stating that the mental process is predominated by the cognition and perceptive processes and encoded in such verbs as 'know', 'think', 'doubt', 'forget', 'feel', 'see', 'hear', 'smell', 'notice', 'remind' etc. Using perceptive processes like 'see', 'hear' suggest that Chinua Achebe through his narrative has dealt with the problem of corruption which he has been an eyewitness in the society by the time he was writing. Also, the cognitive processes encodes in 'know', 'think', 'remind', 'remember' mostly with different characters playing the senser roles, has made it possible to discover that Chinua Achebe was aware of corruption in politics. For instance:

1) When one slave sees another cast into a shallow grave, he should know that when the time comes he will go the same way AMOP 38

2) If I fall down for you and you fall for me then I know it is play AMOP 136

3) I see that you have grown too big for your coat AMOP 111

No 1 proverb was said by Odili, the narrator of Achebe's A Man of the People about Chief Koko's. Chief Simon Koko is the minister of overseas training and a crony of Chief Nanga. He initially is shown as someone who can help Odili obtain entrance to a post-graduate program in London. He promotes the sales of home-made items. But at Nanga's house, he was offered a home-made tea. After drinking it he started crying - 'they have killed me'. This is ironical in the sense that OHMS - Our Home Made Stuff-is being advertised everywhere in the country for people's patronage and here the chief advertiser cried of dying after its consumption, an aspect of corruption. So the narrator by using the processes 'sees', and 'know' shows that this issue of corruption happening in the country at the time he was writing is well known by him. In fact, he has witnessed it, he is also aware of its existence. No 2 proverb is said by Max at the inauguration of CPC, a new party which was founded by Odili, Max and others. To Max, politics is a 'play' and by using 'falling down for you and falling for me' it means that casting vote for election in the country is not voting for the real person who is worthy to serve the masses. Max knows this and he equates it to 'play'. The no 3 is said by Nweke to Odili when he handed him a month salary and a dismissal letter because of party loyalty. 


\subsection{Relational}

Relational processes come the third position and it the process of being which relates to the property of an entity or the relationship between participants. The number of relational process is 16 and 15.5? Analyzing relational process helps the readers to understand the different attitudes towards some of the issues. The following are some of the examples of relational process.

1) Some people belly is like the earth, it is never full that it will like to take another corpse. AMOP 93

2) It is better the water is spilled than the pot broken. AMOP 30

3) My in-law is like a bull he said and your challenge of a tick to a bull AMOP 115

Proverb no 1 is said by one of the people gathered on account of the abomination committed by Josiah. Josiah is a trader. There is this blind man who normally comes to his chop. One day Josiah exchanged the blind man's walking stick. When the blind man noticed this change he started shouting. Here, it is believed that the blind man's stick will be used by Josiah to make money despite the fact that he makes good business in his business. 'Some people's belly' refers to Josiah who is quantified with earth. The writer has used the 'earth' because even if all the people in the world die today, the earth must swallow the whole corpses and be waiting for another. Josiah is compared to earth because apart from profit he makes on daily basis, he would go miles to steal a blind man's stick to make medicine in order to make juju that will blindfold buyers. This incidence tells that the common man is also involved in corruption in Nigeria.

No 2 proverb is recounting the circumstances behind Odili's birth. Odili's mother died giving birth to Odili, the chief character and narrator of the story. Therefore, the water refers to Odili, who should have died instead of the pot, his mother, because if the mother had lived she would have another child or children. All these relationships are possible by means of the use of the relational process 'is.' No 3 proverb is said by Edna's father to Odili when he found out that Odili was vying his in- law's political position. It is an advice for Odili about the danger of such a move. In that proverb, the process 'is' is used to relate Chief Nanga to a bull. Odili challenge is also seen as tick to that of bull.The expression inform of proverb simply means that Odili challenge will never touch Nanga but when Nanga reacts Odili will be wounded.

\subsection{Verbal Process}

Verbal process is the process of saying which involves all kinds of meaning exchange and includes sayer and verbiage. The verbal process was used to indicate the activities of 'saying' and encode the physical act of speaking. In A Moan of the People, it appears 9 times with the percentage of $8.7 \%$. Verbal process is also the fourth frequent process type and the voice of participants other than the narrator is also heard. Verbal processes in the book are encoded in such verbs as 'say' and 'tell'. The characters are freely using proverbs to support one meaning or the other as in

1) Our people say: if you fail to take away a strong man's sword when he is on the ground will you do it when he gets up...?

2) I have said that what the Whiteman's money will bring about had not shown itself yet.

3) He should tell them that we are waiting here like a baby cutting its first tooth anyone who wants to look at our new tooth should know that his bag would be heavy.

The above proverbs are from Achebe's novel. They contain verbal processes: sayer and verbiage. Receiver is also a participant here. The only receiver in the entire book is in proverb no 4 where 'them' represents the political class of Odili and his party members. Max should relate the message of the verbiage to his party members. Here, the sayers: our 'people', 'I', 'he' are used by the writer to present already known opinions. Opinions in the proverbs include the verbiages 1) a strong man's sword is better taking away when he is on the ground. In order words, Edna's father would continue to seek money from his would be in-law (chief Nanga) because when her daughter finally becomes Nanga's wife Nanga would be reluctant to give money 3 . What the whiteman's money will bring has not shown itself. This explains certain atrocities done by persons to get money 3) if Max want their votes his bag should be heavy, that is, for them to vote for him, he should give them money. It is also important to state here that all the verbiages above are all about corruption. 


\subsection{Circumstances}

Table 3. Types circumstances in A Man of the People and their frequencies

\begin{tabular}{lll}
\hline $\mathrm{S} / \mathrm{N}$ & CIRCUMSTANCES & FREQUENCY \\
\hline $\mathrm{a}$ & Extent & 1 \\
$\mathrm{~b}$ & Location (time) & 11 \\
$\mathrm{c}$ & Location (place) & 16 \\
$\mathrm{~d}$ & Manner(means) & 5 \\
$\mathrm{e}$ & Manner (degree) & 5 \\
$\mathrm{f}$ & Manner (comparison) & 7 \\
$\mathrm{~g}$ & Cause (behalf) & 2 \\
$\mathrm{~h}$ & Accompaniment (commutative) & 1 \\
$\mathrm{i}$ & Matter (guise) & 1 \\
\hline
\end{tabular}

For the circumstantials, the story contains only one extent of frequency 'guise', 18 location of time, 11 location of place, 5 manner of means, and degree each, 7 manner of comparison, 2 cause, and 1 of accompaniment, and matter each.

\subsubsection{Extent}

Extent is used in some of the texts to tell us how certain events took place, as seen in the only example seen in the exerpt 'again'. 'Again' a circumstance of extent tells us how corruption is persistent in the country. It happens again and again. Corruption is the way of life in the country.

\subsubsection{Location}

In the following examples, location tells us 'where' and 'when' certain events of corruption took place in the text. Examples:

\subsubsection{Location: Time}

This time, next time, when he goes up, one morning, now, when the time comes, when those standing, when the old woman hears the dance, when you are close to a man, all the time, when he is on the ground.

\subsubsection{Location: Place}

From the rain, on his head, in our country, into his eyes, on the bull's back, in the forest, in this land, into a shallow, from the back of the bull, out, in his mouth, here, at our new tooth, in the proverb, on the ground, there.

\subsubsection{Manner}

In the following examples, Manner tells us how (means) certain events of corruption took place in the text. For example

\subsubsection{Manner: Means}

By a white uniform chauffeur, through the eye of a needle, naked, never,

6.5.3.2 Manner: Degree—enough, yet, so full, only, heavy

6.5.3.3 Manner: comparison—bigger, too big for your coat, as small as, like the earth, like the man, like a bull, like of tick to a bull

\subsubsection{Cause}

In the following examples, Cause tells us the reasons why certain events of corruption took place in the text.

6.5.4.1 Cause: Behalf-for you, for a grasshopper

\subsubsection{Accompaniment}

Accompaniment tells us with/without whom/what certain events of corruption took place in the text.

\subsubsection{Accompaniment: Commutative — with his toes}

\subsubsection{Matter}

Matter (guise) by using 'about' tells us certain corruptible events are guises in the text.

The dominance of location of time and place is not accidental. It shows that actions performed by the participants take place in specific places and time and also in certain manner. Other types like extent, cause, 
accompaniment, and matter are minute, they don't contribute much to the meaning of the text. The implication in the text is that the writer, Achebe, is not after telling us how certain events took place, reason why certain events of corruption took place or to state that certain corruptible events in the novels are guises. But he states categorically that the story he told is about what he witnessed. Therefore, he is aware where, the time, and how it happened.

\section{Conclusion}

The material clauses in the novel signal the actions done by the members of the community to either accept or resist corruption in A Man of the People. Achebe uses them create awareness of some of the things African's do like bribery, moral decadence, taking public money. Mental processes as the process of sensing are used by Achebe to express and ask the people to see, hear, feel, and even think about what was going on in Africa at the time. The exposure to these corrupt practices is for the people of Africa to reflect on these and have a change in behaviour. Relational processes as the process of being are applied to describe, define, identify, and even symbolize something related to Africa's circumstances. Verbal processes as the process of saying convey Achebe's verbal actions which are directed to the African people. Furthermore, the types of transitivity process, participants, circumstatials contribute towards the construction of themes reflected in the novel.

Based on these results, the researcher concludes that Achebe uses a variety of processes, participants, and circumstances to write his novel. This is because he employed almost all aspects of transitivity. Again he uses all kinds of characters: actors, sensers, carriers, identifiers, to present the message of the novel. Achebe mostly uses circumstances of extent, location, and manner to show that all the actions take place in a certain place, time, and at a certain manner.

\section{References}

Achebe, C. (1966). A Man of the people. Heineman.

Achebe, C. (1975). Morning yet on creation day. Anchor Books.

Asika, I. E. (.2013). The portrait of a writer as a wordsmith: Discourse technique in Chinua Achebe's Things Fall Apart (No 50, pp. 136-153). Okike: An African Journal of New Writing.

Augsburg, F. (2011). Types of proverbs. Retrieved from http://www.augsburgfrtress.org

Bloor, T., \& Bloor, M. (2013). The functional analysis of English (3rd ed.). Routledge. https://doi.org/10.4324/9780203538098

Finnegan, R. (1970). Oral Literature in Africa. Oxford University Press.

Fowler, R. (1996). Linguistic criticism. Oxford University Press.

Halliday, M. A. K., \& Matthiessen, C. (2004). An introduction to functional grammar (3rd ed.). Edward.

Huijing W. (2015). The problems of transitivity studies and its solution. Open Journal of Social Sciences, 03, 170-176. https://doi.org/10.4236/jss.2015.310023

Leech, G. N., \& Short, M. (2007). Style in fiction: A linguistic introduction to English fictional prose. Pearson Longman.

Martin, J., \& Rose, D. (2003). Working with discourse: Meaning beyond the clause. Continuum.

Okpewho, O. (1992). African Oral literature: Background, Character and Continuity. Indiana University Press.

Opara S. C. (2017). Aspects of Functional Grammar, A systemic grammar. Gabtony Prints Ltd.

Stubbs, M. (1986). Educational Linguistics. Basil Blackwell Ltd.

Toolan, M. (2010). Language in Literature: An introduction to stylistics. Hodder education.

Umeasiegbu R. (2007). African literature and the oral tradition. Unizik Journal of Arts and Humanities, 9. Retrieved from https://www.ajol.info

\section{Copyrights}

Copyright for this article is retained by the author, with first publication rights granted to the journal.

This is an open-access article distributed under the terms and conditions of the Creative Commons Attribution license (http://creativecommons.org/licenses/by/4.0/). 